\title{
Squamous cell carcinoma of the gallbladder
}

D epartments of Digetive Surgery and Pathology, H ospital do Servidor Público Estadual, São Paulo, Brazil

Squamous cell carcinoma (SCC) of the gallbladder is a rare and aggressive affection and is responsible for up to $12.7 \%$ of the malignant neoplasms of this organ. ${ }^{1,2,3}$

It characteristically presents invasive growth, a low tendency towards lymph node metastases and a high incidence of local infiltration and hepatic metastases, presenting a worse prognosis than adenocarcinoma of the gallbladder. ${ }^{1,2}$

In the period between 1968 and 1998, three patients suffering from squamous cell carcinoma of the gall bladder were operated on in our D epartment. They died between 1 and 6 months after the surgery (Table 1 ).

SCC of the gallbladder is predominantly incident among females, in a proportion of 3:1 over males, and between the fourth and sixth decades of life, ${ }^{1,2,3}$ as was found in our cases.

Its rapid growth, early metastatic dissemination and diffuse local and regional infiltration characterize the biological behavior of the lesion. Such tumors tend to grow laterally along the fossa of the gall lbladder, forming large infiltrative masses and invading the liver and adjacent organs (stomach, duodenum and transverse colon) by direct expansion. ${ }^{1,2}$ This pattern was verified in the cases here described. D espite this local and regional infiltration, it usually does not present metastases in lymph nodes, and seeding in the peritoneum is rare. ${ }^{3} \mathrm{~N}$ evertheless, hepatic metastases, as seen in case 2 , are more frequently found in SCC than in adenocarcinoma of the gallbladder. ${ }^{1,2,3}$

M ost studies accept that the squamous cells originate from pre-existing metaplastic squamous epithelium; some others believe that SCC of the gall lbladder originates from squamous differentiation of the adenocarcinoma cells, via expression of mixed phenotypes within a single tumor. ${ }^{1,2,3} \mathrm{C}$ haracteristically, the duplication timefor SCC is half that of adenocarcinoma, such that the growth of SCC cells may overtake and substitute that of adenocarcinoma. ${ }^{1,2}$

D isease is suspected when the lesion reaches a large size and is locally advanced, which was also observed in the cases we studied.

The surgical options available depend mainly on the degree of local and regional involvement and consist of cholecystectomy with resection of a wedge of adjacent liver tissue or direct liver resection allied with regional lymphadenectomy and skeletization of the hepatic hilum..$^{2,4}$

Resection of the organs involved as part of the radical operation is justified in cases of localized lesion, without metastases or peritoneal dissemination. H epato-pancreatic duodenectomy was introduced as a radical treatment option for SCC of the gallbladder because of the type of dissemination seen in squamous cell carcinomas. ${ }^{4} \mathrm{H}$ owever, its long-term benefits have not yet been satisfactorily documented.

Adjuvant postoperative radiotherapy and chemotherapy may be used, although their results are inconsistent and only palliative. ${ }^{1,2}$

The extent of thetumor at the time of diagnosis is the most important parameter in determining survival. ${ }^{2,3}$ The majority of thepatients diearound six months after diagnosis when radical surgery is not performed, ${ }^{1,4}$ as occurred with the patients described. These data reinforce the idea that early diagnosis is the most important parameter for improving the survival indices among patients with SCC of the gallbladder.

Jaques Waisberg, MD. Department of Digestive Surgery, Hospital do Servidor Público Estadual, São Paulo, Brazil.

Sansom Henrique Bromberg, MD. Department of Digestive Surgery, Hospital do Servidor Público Estadual, São Paulo, Brazil.

Maria Isete Fares Franco, MD. Department of Pathology, Hospital do Servidor Público Estadual, São Paulo, Brazil.

Nagamassa Yamagushi, MD. Department of Digestive Surgery, Hospital do Servidor Público Estadual, São Paulo, Brazil.

Paulo Amaral dos Santos. Student of Medicine, Faculdade de Medicina do $A B C$, Santo André, Brazil.

Mário Augusto Padulo Castro. Student of Medicine, Faculdade de Medicina do ABC, Santo André, Brazil.

\section{REFEREN CES}

1. H anadaM , Shimizu H, Takami M . Squamouscell carcinoma of thegall bladder associated with squamous metaplasia and adenocarcinoma in stu of the mucosal columnar epithelium. Acta Pathol Jpn 1986;36:1879-86.

2. Karasawa T, Itoh K, Komukai M et al. Squamous cell carcinoma of gallbladder- Report of two cases and review of literature. Acta Pathol Jpn 1981;31:299-308.

3. Khaira HS, Awad RW, Thompson AK. Squamous cell carcinoma of the gallbladder presenting with a biliary-colic fistula. Eur J Surg O ncol 1995;21:581-2.

4. M iyazaki K, Tsutsumi N , Kitahara K, et al. H epatopancreatoduodenectomy for squamous and adenosquamous carcinoma of the gallbladder. Hepato-G astroenterol 1995;42:47-50.

\footnotetext{
Address for correspondence:

Jaques W aisberg

Rua das Figueiras, 550 - Apto. 134

Santo André/ SP - Brasil - CEP 09080-300

E-mail: jaqueswaisberg@uol.com.br
}

\begin{tabular}{|c|c|c|c|c|c|c|}
\hline Case & Age & Sex & Finding & Operation & Lesion & Survival \\
\hline 1 & 68 & female & invasion of hilum & Biopsy + T-tube & SCC grade III & 1 month \\
\hline 2 & 52 & female & hepatic metastasis & cholecystectomy & SCC grade II & 6 months \\
\hline 3 & 74 & female & invasion of hilum & biopsy & SCC grade III & 2 months \\
\hline
\end{tabular}

